\title{
Sustainability and Authenticity of Chinese Traditional Crafts in the Contexts of Luxury and Tourism
}

\author{
Kelly Meng and Michael Hitchcock
}

Goldsmiths, University of London

Corresponding Author: K.Meng@gold.ac.uk

\section{ARTICLE INFO}

Received

6 August 2020

Accepted

31 August 2020

Available online

30 September 2020

\section{ABSTRACT}

Chinese crafts have been examined from economic, historical and aesthetic perspectives, but rather less attention has been devoted to them in the literature on luxury and tourism. When considering the former, it is worth noting that some of the world's leading brands had their origins in craft businesses, notably Louis Vuitton, and that craft skills remain important for this industry in the 21 st century. On the other hand, there is a common assumption that craft souvenirs represent a cheap and debased version of human material culture but, as many academics have asserted souvenirs come in a wide variety of forms, including what Graburn (2000) has called 'pride goods', in which peoples visited by tourists sell products that are simultaneously economically useful and boosters of esteem on behalf of the producing community. It is with these thoughts in mind that we turn our attention to the production of Chinese craft products in the early 21 st century. As one of the leading handicraft producers in the world, the expanding demand for Chinese craft products has generated commercial opportunities and strong economic returns, it has also created challenges to the Chinese traditional crafts sector which may influence the direction and sustainability of its future development, and as such is worthy of deeper investigation and discussion.

Keywords: Chinese traditional crafts, luxury, tourism, sustainability, authenticity

\section{INTRODUCTION}

China is one of the leading handicraft producers with around 30\% share of world trade (Ernst \& Young 2012). According to a report published by the United Nations Educational, Scientific and
Cultural Organization (UNSECO) in 2016, the growth rate of China's exports of 'cultural goods of visual arts and crafts' between 2004 and 2013 was 735\%, five times greater than her runner-up state, the USA. While the expanding demand for Chinese craft products has generated 
commercial opportunities and strong economic returns, it has also created challenges to the Chinese traditional crafts sector which may influence the direction and sustainability of its future development, and as such is worthy of deeper investigation and discussion.

Chinese crafts have been examined from economic, historical and aesthetic perspectives, but rather less attention has been devoted to them in the literature on luxury and tourism. When considering the former, it is worth noting that some of the world's leading brands had their origins in craft businesses, notably Louis Vuitton, and that craft skills remain important for this industry in the $21^{\text {st }}$ century. On the other hand, there is a common assumption that craft souvenirs represent a cheap and debased version of human material culture but, as an edited collection by Hitchcock and Teague (2000) showed, souvenirs come in a wide variety of forms, including what Graburn (2000) has called 'pride goods', in which peoples visited by tourists sell products that are simultaneously economically useful and boosters of esteem on behalf of the producing community. It is with these thoughts in mind that we turn our attention to the production of Chinese craft products in the early $21^{\text {st }}$ century.

In this paper, we review the issues and challenges that the Chinese traditional craft sector is facing due to the historical http://ojs.unud.ac.id/index.php/eot transformation, before we propose a 'luxury approach' as a strategy to seek for a more sustainable trajectory of development. What should be noted from the outset is that this work refers to the products of the Han Chinese, the country's major ethnic group, and not the country's renowned minorities, though the authors have been inspired by work in this area by authors such as Gina Corrigan (2002).

\section{CRAFT \& ART}

The ultimate etymology of the English term 'craft' is uncertain, but there does appear to be a strong link with the various versions of the Germanic and Nordic term 'kraft', which has connotations of 'strength' and 'power' and more infamously with the Nazis use of the term in the slogan 'kraft durch freude' or 'strength through joy'.

The Germanic/Norse sense of the term was expanded in Old English to include notions of skill, dexterity, art science and talent and something that was built or made. Mediaeval cities later became centres for guilds built around collectives of crafts producers and the idea that they embodied 'mysteries', which later evolved into 'worshipful companies' and later charitable organisations as the need for skilled craftwork declined as Britain industrialised. Indeed, the authors of this 
paper both work for Goldsmiths College, which was founded by the descendants of the old precious metalworking guild of that name.

The terms 'craft' is also often association with notions of 'tradition', though this is not invariably the case. However, as this paper discusses Chinese crafts, which have a long history it is worth considering what 'traditional' actually means, especially in its etymological sense in English which contains notions of beliefs or practices handed down over the generations. Ultimately, it has origins in the Jewish sense of tradition based on Mosaic Law, but appears to have come into English from the late $13^{\text {th }}$ century French concept of 'tradicion', meaning transmission or handing over.

In other words, there is association of passing down knowledge or skills over the generations, though not invariably with the same family, and thus has relevance in the Chinese context where notions of tradition are closely associated with the concept of culture (文化wehua). The term appears to be derived from 'wen (文) ', which is associated with the weaving of colours, ornamentation and goods, and 'hua

(化) , meaning variation, creation and formation.

There was period of time when craft was considered irrelevant to any kind of http://ojs.unud.ac.id/index.php/eot creative work (Greenhalgh 2002), but we started rethinking the value of 'craft' when the field of crafts begun to shadow impacts on our societal values. In modern history, it was almost 150 years ago when 'craft' last evoked scholarly debates among various academic disciplines. The 'Arts and Craft Movement' was sparked in the 1880s in Britain, largely as a reaction against the deficient product quality of mass mechanical production and the deprived social status of decorative art - craft objects with a functional nature (Risatti 2007, Greenhalgh, 1997 \& 2010).

Since then discussions surrounding the craft and art relationship has never quite resolved the questions whether 'craft' should be separated from 'art', or could legitimately be defined as 'art'. LeesMaffei and Sandino (2004: 207) believed the principle of defining (or differentiating) craft and art was to take into consideration the many changes occurring in any given historical, socio-cultural and geographical context.

During the $20^{\text {th }}$ Century, the boundary between craft and art became blurred. Greenhalgh (2002:1) pointed out that, whilst craft has been gradually "corralled into a particular enclosure", it is necessary to reflect on the emerging agendas (such as digitalisation in work design and product distribution) in the current field of craft, because these will e-ISSN: 2407-392X. p-ISSN: 2541-0857 
manifest, unfold and impact on our society in the coming years. And now, just as we did more than a century ago, we need to rethink craft and re-evaluate its strategic relations with art (Shiner 2012).

In the final report jointly presented by UNSECO and the International Trade Centre (ITC), crafts were defined as the "products that are produced by artisans, either completely by hand or with the help of hand-tools or even mechanical means, as long as the direct manual contribution of the artisan remains the most substantial component of the finished product" (UNESCO \& ITC, 1997: 6). It goes on to conclude that the distinctive features of crafts "can be utilitarian, aesthetic, artistic, creative, culturally attached, decorative, functional, traditional, religiously and socially symbolic and significant which attribute to the special nature of artisanal products" (ibid). As Greenhalgh (2002:1) argued "crafts are a consortium of genres" which have been "deliberately placed together" but can "make sense collectively for artistic, economic and institutional reasons".

Greenhalgh's remark might sound harsh, but it indicates some important properties of crafts which help define and justify the identity of crafts and craftspeople, and being institutionally connected is one of them. Furthermore, both Thornton (2002) and Shiner (2012) http://ojs.unud.ac.id/index.php/eot contended that it is the multifaceted institutional nature of craft industry that has shaped the developing trajectory of 'craftworld' in the western culture, and it has certainly happened in China too, but often with more political interference.

\section{A CHINESE VIEW OF CRAFTS, CRAFTSMAN AND CRAFTSMANSHIP}

\section{'Crafts' in Chinese Translation}

What is significant is that crafts people have long had a clearly defined space in Chinese culture dating to the late Zhou Dynasty (1046-221 BCI). Scholars belonging to the legalist or Confucian tradition recognised four categories of people based on occupation which were $s h i$ (gentry or scholars), nong (peasant farmers) gong (crafts people) and shang (merchants and traders). These occupations were not invariably organised in this order and they were not seen as socioeconomic classes and were not hereditary. This arrangement stands in sharp contrast to two other major civilisations - India and Europe - where the role of crafts people has been studied in detail and in which heredity and social standing was accorded great significance in the pre-industrial era.

What is also interesting about China is that its crafts people attracted the attention of its renowned sages, namely Mozi (c.470-391BC) who is thought to 
have come from a lower artisanal background and managed to make his way in to the literary class or gentry. He was born in Tengzhou in what is now Shandong Province and there is some suggestion that his youth was troubled and that he was branded because of his misdemeanours and that his name, Mozi, which is not his original name but literally means the tattooed master (Eno 2010: 1), reflects this.

However, he seems to have overcome this inauspicious start to serve as a minister in the state of Song and to open a school for students who wished to become officials. Mozi argued against the betterestablished schools of thought of Confucianism and Daoism, placing emphasis on self-restraint, self-reflection and authenticity as opposed to obedience to ritual. He was also renowned as a carpenter and is attributed with designing a wide variety of mechanical objects ranging from water moving utensils to siege engines.

His life is celebrated in the Mozi Museum in Shandong Province and current interpretation places him as something of working class and modern day Communist hero who designed tools that eased the lives of working people. His followers were mostly crafts people and technicians who were organised in a disciplined manner in the study of Mozi's technical and philosophical writings. In particular, the sage exhorted his followers to lead an http://ojs.unud.ac.id/index.php/eot ascetic and self-restrained way of life and to renounce material and spiritual extravagance. It would not be misplaced to say that even in the 21 st Century, the spirit of Mozi lives on among contemporary crafts people. The key point in relation to this discussion is Mozi's focus on authenticity, a term which frequently crops up in discussions with contemporary craft practitioners in China.

The Chinese term 'Gong Yi Mei Shu (工艺美术)' was first introduced by Chinese educator Cai Yuanpei in his book The Origin of Art in 1920 (Zhu 2009), which was a direct reference to the European and North American Arts and Crafts movement (and the later Japanese Mingei movement). Educated in Japan and influenced by western culture, Cai intended to import advanced Western thinking to China, however his translated Chinese phrase did not fully convey the two components of 'arts and crafts'.

'Gong Yi' can be closely translated as 'crafts' in the Chinese context, but 'Mei Shu' was a orthographically borrowed word from the Japanese 美術 (bijutsu), meaning 'beautiful technique' or 'techniques of creating aesthetic objects'. Whilst in the Japanese language 'Mei Shu' is equivalent to 'fine art' in the English sense, but in the context of the Chinese language it doesn't completely pair with the 
meaning of 'fine art' encoded in the English language. And later when 'design' emerged from Germany as a new notion pioneered by Bauhaus with the aim of combining crafts and fine art, 'Mei Shu' was not able to reflect or connect to the new concept (Zhu 2009, Tian 2010). As a consequence of this combined complication, the term 'Gong Yi Mei Shu' has long stimulated debate among Chinese scholars, policymakers and industry practitioners.

\section{A Dividing Line Between Crafts and Art}

After the communist party became the ruling party in 1949, the term 'Gong Yi Mei Shu' became commonly perceived by the public as synonymous with handicrafts in the wider Chinese social context, and it particularly applied to the traditional handicrafts that were exclusively manufactured for the purpose of overseas exports after 1950s (Zhu \& Xu 2010, Zhu 2009). However, within academic circles divisions emerged as to whether 'Gong Yi Mei Shu' should be treated as a singular term which placed emphasis on artistic design, or should focus in a rather more limited sense of 'crafts' and specifically 'handicrafts' (Zhu 2009).

Before 2012, most degrees offered by Chinese higher education institutes (e.g. universities) were related to artistic design with the incorporation of western theory and techniques (Tang \& Tao 2014), whereas on the other hand teaching and training in the design and production of crafts were conveyed through occupational schools. The consequence of this divergence within the educational system was that students graduating with a higher education degree would have a much better chance to gain access to professional jobs within the arts and crafts sector which might be labelled 'white collar', and who would thereby be considered to have a higher social status, as well as better income and career progression prospects. In contrast, students fully trained in the skills needed to produce crafts would be most likely to become 'blue-collar' workers who would normally work with their hands to produce physical products, but would garner less social respect and lower remuneration.

It seems the dividing line between crafts and art is quite clear in China, and is noticeably reflected in the differing social standing of craftsmen and artists. In addition, the social status of Chinese craftsmen has traditionally been embedded within the hierarchies of Chinese society. Furthermore, the craftsmen community is further divided into levels based on the degree of association that craftspeople are able to claim with the country's hierarchical institutions, which means the closer craftspeople are able to link with the central e-ISSN: 2407-392X. p-ISSN: 2541-0857 
governmental powers (such as the imperial courts and aristocracy communities in ancient China, and now most likely the PRC party apparatus), the more they are respected and hence their crafts are more visible, valuable and collectable (Xu, 2016).

Some Chinese scholars contest that the association between the Chinese crafts industry and political power is not in fact driven by the commercial market, but instead constitutes the typical political behaviour exerted within government circles. A consequence of this political behaviour is that, once a particular type of craft becomes a 'special supply' to the central political powers, the mass public will have restricted or zero accessibility to these crafts, whilst paradoxically possession of a rare item handmade by the favoured craftspeople with a higher social status or stronger political connections will be considered as the symbol of power.

\section{Disappearing Craftsmanship}

In common with other Asian courtbased societies, a great deal of artisanal production in China was clustered around royal and noble centres. The demise of this kind of patronage following the establishment of the Republic has long posed a threat to the viability of these traditions. The expansion of domestic and inbound tourism since the 1980s has offered a potential source of revenue. For example, for Japanese tourists the purchase of a high end souvenir often represents the second largest expenditure after the purchase of the holiday itself.

What seems to have been neglected or overlooked over the last 100 years by the Chinese society and polity is that the skills and often localised specialisations associated with craftsmanship is something that has accumulated and evolved over centuries. In Western culture, people honour and appreciate the virtues of craftsmanship which may typically be considered to be the most important assets to the craft industry, to be nurtured, inherited and promoted (van Bergen 2017). There is a common acknowledgement, shared by both western and Chinese culture, that traditional craftsmanship embodies the crafts people's supreme skills, the extremely high quality and intricate detail of craft products and the sense of craftsmen "giving themselves to their work" (Bergadaà 2008:11, Xu 2016). But what has caused China gradually to lose some of the essence of its craftsmanship over the last century can be summarised mainly through three stages (Xu 2016): the dismantling of imperial power in the early $20^{\text {th }}$ Century, which reduced the demand for high-end crafts by 
the royal court and the aristocratic communities.

The second phase was during the period of Chairman Mao's leadership, when the central government had to prioritise the political focus on 'meeting people's basic needs' due to widespread poverty and product shortages, with crafts being given a lower priority, and high-end crafts shunned for their bourgeois associations. The Open Doors policy since the 1980s, meanwhile, has allowed wider access to national and international markets, but at a cost of mass and intensified production of craft items of questionable quality, and which has even earned for China a reputation of being the world's largest "provenance for counterfeit goods" (Europol \& EUIPO 2017: 6).

Within such a commercial environment it has been very difficult for many Chinese crafts to stand out in international markets on the basis of the quality of craftsmanship, not least because craft themes are often related to Chinese myths and legends that are often unfamiliar to peoples abroad. Considerable interpretation may be required therefore to make these stories understandable and possibly at some cost.

\section{Reinstating Chinese Craftsmanship}

Since Chinese Primer Li Keqiang introduced the concept of the 'spirit of craftsmanship' in his government work report in March 2016, all genres of professions in the entire nation have since tried to fathom the concept. But what exactly does the new concept imply for Chinese society? Setting up as a central governmental project, the Chinese government wanted to encourage the nation in all industries to improve professional techniques and refine product quality in order to restore consumers' confidence towards domestic products in the face of fierce competition from foreign products.

Moreover, in 2017 the government released a 'Plan to Revitalise the Traditional Crafts', which aimed to "further promote traditional Chinese crafts" and "inject momentum into the protection of Chinese culture and heritage" (Hu 2017), with the objectives of increasing job opportunities and enhancing product diversity within the craft industry. What, then, are the particular implications of the 'plan' for the Chinese craft industry, as well as to the thousands of craftspeople in China?

Apart from pursuing professional excellence, the notion of 'craftsmanship spirit' is more about promoting a particular set of moral values, which had become 
understated in the money-driven society. But in his well-cited book, Sennett (2008) claimed moral imperatives only work for better results in a situation where they are institutionally organised. Since China rolled out the new concept as a national project, both central and local governments will provide sufficient policy and financial support, but the fine spirit that craftspeople traditionally held may take time to rekindle and require more interpersonal and emotional inputs to nurture (Coeckelbergh 2014).

In the following paragraphs, we are going to open discussion of the challenges that the traditional Chinese crafts face against this backdrop, as well as exploring the potential opportunities which the Chinese crafts sector might enjoy in the luxury segment of the market - something Chinese-made products have largely been absent from hitherto despite China having become one of the world's largest consumers of luxury goods.

\section{SEARCHING FOR AUTHENTICITY - A CHALLENGE FACED BY TRADITIONAL CHINESE CRAFTS}

Traditional Chinese crafts generally refers to "a variety of handicrafts and techniques that have existed for over one hundred years and [are] marked by a long history, exquisite skills, have been passed on from generation to generation, have a http://ojs.unud.ac.id/index.php/eot complete technical process, have been made of natural materials, have a distinct national style and local features, and are renowned both at home and abroad" (State Council of the PRC 1997).

Bearing in mind the official definition, if we conduct a quick survey of the international auction houses in terms of their major bidding deals in recent years, it is not difficult to notice that both Chinese traditional crafts and Chinese buyers are near the top of the lists on both bidding sides (e.g. Sotheby's and Christie's). Also, in many major international art museums, we often find a particular section dedicated to traditional Chinese crafts (e.g. Victoria and Albert Museum) ambiguous understanding of the characteristics of 'authenticity' under different circumstances. Accordingly, we will explore the meaning of authenticity in the context of Chinese traditional crafts in two specific contexts: tourism and branding.

\section{Authenticity in the context of luxury branding}

Authenticity is a concept that has been widely researched but often overused, particularly in the field of marketing. A widely held position is that authenticity is important for consumers and that customers want to acquire something that is real and not something that is fake (Gilmore and Pine, 2007), though as these authors e-ISSN: 2407-392X. p-ISSN: 2541-0857 
concede that authenticity can be seen in a variety of ways and its prominence may vary from one enterprise to another. To simplify a somewhat complex series of arguments, the essence of authenticity lies in the ability of companies to build brands in which consumers have faith and confidence that the products they are buying are somehow rooted to tradition, locality or genuine craftsmanship.

Research findings suggest that consumers' perceptions with regard to the authenticity of the products and the locations where they make purchases tend to influence their consumption behaviours (Ramkissoon \& Uysal 2011, Kim \& Bonn 2016, Fritz et al. 2017). Hede and others (2014, p 1395) tested and confirmed that "consumer scepticism and expectations are antecedents to perceived authenticity of the visitor experience" under the research context of museum in which curatorial expertise provides validation.

Bergadaà (2008) claimed the experience of authenticity in relation to craft industry falls into three fields: the objects of artistic craftsmanship; the professionalism of craftspeople; and the relationship that is built during the interaction of consumers and craftspeople in relation to the cultural and aesthetic experience associated with crafts production.
Furthermore, affluent consumers (the mainstay of the luxury markets) are searching for authenticity beyond physical objects, which may sometimes be artificially branded with 'authentic features'. Instead, they pursue the authentic values embedded in the physical object which is "secured by craftsmanship, scarcity of supply, unique aesthetics, the link to the origin, non-necessity, and the high price" (Hitzler \& Müller-Stewens 2017: 53).

Concurrently, luxury brands view authenticity as a prime parameter to differentiate themselves from mass others (Heine et al, 2016; Hitzler \& MüllerStewens 2017), and therefore strive to exhibit their excellence and perfection through authenticity in every aspect of their business, as part of their overall management strategies (Hitzler \& MüllerStewens 2017). From this point of view, the traditional Chinese crafts are able to match with these 'luxury credentials' in the sense of offering 'authentic value', which is one of the factors that help explain why some traditional Chinese crafts are frequently among the top-priced transactions made on both domestic and international antique auction markets.

However, what is particularly interesting about Chinese consumers is that, for them, the emphasis on authenticity has a slightly different manifestation, with e-ISSN: 2407-392X. p-ISSN: 2541-0857 
less emphasis on a perceived binary relationship between authentic and inauthentic products (Liu, Yannopolou, Bian and Elliott 2015). The authors suggest that Chinese consumers evaluate authenticity in relational and hierarchical terms as opposed to uniqueness and originality, with two authenticity types emerging - domesticated and mimicked (ibid.).

What seems to be emerging from this research is that the Chinese place an emphasis on 'brand equity' and long-term relationships with consumers, but this is potentially problematic in the context of tourism where craft makers often do not have meaningful and clearly identifiable brands, and are unlikely to engage in longterm relationships with consumers.

\section{Authenticity in the Context of Tourism}

Many Chinese craft producers sell their wares in the context of tourism, which has a huge domestic dimension. Even though the customers often share the same culture as the producers, many craft makers complain the buyers are not very interested in traditional themes and are driven by questions of price rather than quality. A common refrain is that craft producers are being pushed by the demands of this market to produce goods that are not authentic in terms of traditional craftsmanship. Several scholars in the field of tourism studies have been investigating the impacts of tourists on the authenticity of handicrafts, with much research focusing on East and South East Asia (Graburn 1984, Parnwell 1993, Bruner, 2005, Wherry 2006, Chang et al. 2008). It worth considering their main observations at this juncture as an additional set of issues comes to the fore, such as the notion of the 'staged authenticity' of tourist attractions (McCannell 1973), 'objective authenticity' (Wang 1999), which is further elaborated by Steiner and Reisinger (2006) and Lau (2010), as well as 'constructed authenticity' and 'existential (subjective) authenticity' (Cohen 1988).

Cohen and Cohen (2012) point out that the "...three discourses are not on the same level: while objective (object) authenticity and existential (subjective) authenticity denote different types of (personally experienced) authenticity, constructed authenticity does not; rather, it relates implicitly to the process of social construction of the other two types". In an attempt to get to the heart of the authenticity debate in tourism, Tom Selwyn (1996) offered the distinction between "hot" and “cool” authenticity. Selwyn (1996: 20-21) conceived of "hot" authenticity as that "aspect of the imagined world of tourist make-believe...concerned with questions of self and society," in particular with the e-ISSN: 2407-392X. p-ISSN: 2541-0857 
quest for an "authentic self" and "authentic other." Selwyn distinguishes the concept of "cool" authenticity as reserved for propositions which aim to be open to the kinds of procedures described by Popper [i.e. are subject to falsification]. Selwyn appears to distinguish between a "social" and a "scientific" version of authenticity, or in more theoretical terms, an "emic" and an "etic" one - one experienced by the tourists, the other representing a theoretical topdown approach (Cohen and Cohen 2012). But what about the situation in China?

The meaning of the term 'authenticity' in China seems to have a sense which does not differ much from the English use of the term in which authenticity is seen as embodying something that is original and is not a copy. It might also be added that there also the curatorial sense of the word which may be captured in terms such as expertise (of the scholar/curator), provenance (origin), materials, association, name (often in the langue of the place of origin), documentation, measurement and photographic record. In fact, it is often these features that have pride-of-place in a museum's documentation, and a great deal of effort goes in to the accuracy of the records on file.

Similar concerns are also seen in the authentication of high quality crafts and luxury goods, which are often http://ojs.unud.ac.id/index.php/eot interchangeable. All of the above curatorial concerns appear to be taken into account with an underlying desire to protect the authenticity of the creator's products and in particular the creator's or company's intellectual property. This is not just a matter of pride as there is a very strong underlying business imperative to protect the producer's brand and identity, not least because of the threat of copying without the initial investment in creating. This means that the brand or company that created a given object risks losing its initial investment if it is simply copied by another commercial concern that did not have to invest in the creativity vested in a high quality and desirable item.

There are "craft experts" - both Chinese and foreign - who can provenance crafts and understand the significance of their patterns, style and manner of manufacture, in other words 'cool authenticity'. However, some Chinese crafts have considerable "kerb appeal" and there are now many varieties designed to appeal to tourists - 'hot authenticity'. But these new forms of "Chinese crafts" may not be rooted in the tangible and intangible heritage of traditional crafts, though the results are often pretty impressive. Creativity may be defined as a phenomenon whereby something new and of value is formed. Creativity may be intangible (e.g. music, stories, humour) or e-ISSN: 2407-392X. p-ISSN: 2541-0857 
tangible (paintings, sculptures, buildings). While traditional Chinese crafts would at first glance appear to be tangible, there are intangible elements associated with the symbolism of certain designs. While such items may be readily intelligible to Chinese purchasers, foreigners are often in need of interpretation, as they may not be familiar with the stories or symbolism inherent in such objects. Why is it important to consider tourism?

The position of Chinese traditional crafts in tourism is mixed. 'Authentic' traditional crafts may be collected by knowledgeable tourists, both domestic and foreign, and there is a market for high-end crafts that acknowledge the ancient traditions of China but have taken them to new creative heights. Interestingly, these exclusive crafts are often designed by very small companies making very high valueadded products, but what about the popular market? Informal questioning of tourists and an examination of blog posts where China's craft products are mentioned, indicates that, for Western tourists at least, traditional craft products have limited appeal. The themes, uses and associations of these crafts are often unknown, though there is a growing literature. There is also limited use of the "co-creation of experience" model in China, where the purchaser and the producer come together in a shared creative undertaking. It is these http://ojs.unud.ac.id/index.php/eot contexts where interpretation can enhance the value-added, not least because tourism is moving on to the consumption of experiences

It would appear that many small and medium-sized producers of crafts, as well as some major concerns, are focused on the home market, and seem to assume that their products automatically have international appeal. The 'authenticity' and 'creativity' of these companies can be directed at the international tourism market through clever designs, shops displays and social media.

\section{CAN 'LUXURY BRANDING' PROVIDE AN OPPORTUNITY FOR CHINESE TRADITIONAL CRAFTS?}

It may sound irrelevant or controversial to bring 'luxury' into the current research context, but what many luxury brands have experienced in the last century could have some implications for the development of Chinese traditional crafts in both the domestic and international markets. Rebecca van Bergen (2017) asked if fine European craftsmanship contributed to the success of many internationallyrenowned luxury brands, why hasn't this happened in the rest of the world? It is an even more sarcastic question to ask in the Chinese context: whilst there are thousands (perhaps millions) of skilled craftspeople mastering all forms of traditional Chinese craftsmanship, and China's export of craft 
products is in the leading position in the international trade market, why has China only earned herself a very damaging reputation with the label 'made in China'?

On the other hand, if we examine closely those international (mainly European) luxury brands with more than 50 years' history, their products and experiential qualities seem to share certain common features: these include historical heritage and cultural attachment, unique know-how (craftsmanship), the longlasting quality of the product (and experience), a restricted and selective distribution system, personalised service and excessive prices, and above all a sense of privilege brought to the owners who purchase or possess the products (and experiences) (Kapferer \& Bastien 2012: 47). It is not difficult to find certain of these 'luxury features' (such as historical and cultural attachment, craftsmanship) also associated with Chinese traditional crafts, as we have discussed in the previous sections. But other components such as product quality and consistency, distribution system, and personalised service, still require further development in order to restore the reputation of traditional Chinese crafts and deliver a sense of 'privilege' to the consumer.

\section{Building Luxury Brands for Chinese Traditional Crafts}

Theoretically, building a luxury brand requires two fundamental elements, which are the historical heritage to which the brand is attached, and a convincing story the brand can tell to luxury consumers (Kapferer \& Bastien 2012). China is hardly deprived of either element, which means traditional Chinese crafts possess the fundamentals to metamorphose into luxury products and experiences. However, what seems missing here is the 'brand' - an identifiable name that can represent the beauty of the traditional Chinese crafts and differentiate them from the competitors in the market.

However, it is only very recently that China has evinced an intention to build brands that seek to exploit the country's historical inheritance. While most famous brands in the luxury industry globally have striven for innovation and market expansion since the end of WWII, Chinese brands have often moved in the opposite direction, going through a process of nationalisation in the 1950s, and further recession during the Cultural Revolution. The economic reforms of the late 20th Century enabled China to open up to global markets, but while mass-produced but lowpriced Chinese goods have contributed significantly to GDP growth in China, this has occurred at a cost of a Chinese brand 
image that is often associated with inferior quality.

It was not until 2006 that the Ministry of Commerce of the PRC (MOFCOM) announced the first 434 Mainland Chinese enterprises to be the recipients of the designation 'China Timehonoured Brand', with the aim of promoting famous Chinese domestic brands. Until now, 1128 brands have been recognised in the list, together with an average of 140 years' establishment history (Ge \& Wang 2018). However, a mere twenty-one of these brands (2\%) are in the category of 'art and craft', with a few more craft brands (e.g. the Gong Qian bamboo fan) included in the category of 'processing and manufacturing'. ${ }^{1}$ While perhaps the 'made in China' label has stained Chinese brands' reputation in the global markets, particularly in the segments of daily use objects and counterfeit luxury goods, how can this handful of 'China Time-honoured Brands' battle against the prevailing brand image for Chinese traditional crafts?

\section{Developing a Sustainable Brand for Chinese Traditional Crafts}

Is Brand Ownership a Myth?

It may take quite some time for many Chinese traditional crafts to build a brand and revitalise their brand image in both domestic and international markets. Accordingly, it may be more realistic to take a closer look at some of the established 'time-honoured' crafts brands which are recognised by the central government. A few questions may be asked here: how many of these brands are well-known by domestic consumers, particularly the younger generations (e.g. the millennials)? How much is knowledge of the brands appreciated and highly valued by the mass market? And ultimately what are the 'strategies' to sustain the brands' development? The following text will discuss four agendas in relation to these questions, starting with the ownership of the brand.

In the luxury industry, there is a universal principle that 'the brand comes first' (Kapferer \& Bastien 2012)! The luxury brand owner, whether it is a family or a group, views the brand name as one of most important assets for the enterprise. The brand owner has authority and freedom to steer brand strategies within the enterprise, with the best intention to promote the brand name. In the meantime, the brand owner has all forms of rights to protect the enterprise when the brand name is under threat. The essence of the brand name always stays within the enterprise,

\footnotetext{
${ }^{1}$ Source of statistics: http://zhlzh.mofcom.gov.cn http://ojs.unud.ac.id/index.php/eot
} 
and the brand owner is the guardian and guide for the brand.

However, the situation in China seems more complicated for the traditional crafts: obviously many traditional Chinese crafts have manged to maintain the original brand names as they were first established, but the brand owners have not necessarily stayed within the brand family due to the nationalisation policies of the Maoist era, though interestingly the early Communist leaders espoused their support for what they considered to be 'time honoured' brands (China Daily 15 ${ }^{\text {th }}$ August 2011). Now, in order to rejuvenate authentic craft brands, the government intends to 'reconnect' the brand name with the original brand founding family, often through the use of social media (Barclay 2017) but this is challenging given that the original brand essence has been long lost over the past 50 years (Li \& Ma 2017). So, perhaps the first challenge faced by both sides is to search for the original brand essence and reposition the brand to adapt to the current market.

Importance of Brand Protection

Brand protection is the second agendum that has to be taken into serious consideration once the brands start trading on both international and domestic markets. In order to protect their vital brand asset, luxury brands have always armoured http://ojs.unud.ac.id/index.php/eot themselves with layers of protection for their intellectual property rights, ranging from international treaties (e.g. WIFO) to regional agreements (e.g. EUIPO) and domestic legal regulations. For example, Christian Louboutin devoted six years to the battle against a rivalry company who had replicated the distinctive scarlet red sole; Gucci engaged in a 9-year-long international court case to fight for trademark rights against Guess; and there are many more examples that might be cited. It might be unrealistic to expect the traditional Chinese craft people to equip themselves with legal protection similar to the world-famous luxury brands, not least given weaknesses in the country's own intellectual property protection legislation, but it is nonetheless necessary for them to acquire and equip themselves with knowledge of the forms of protection they require to guard their own intellectual property in relation to craft work.

China has been rather late in developing and enforcing effectively a legal protection system for IPR, which has clearly not helped crafts producers to nurture a conducive atmosphere. The "Regulations on Protection of Traditional Arts and Crafts" were first issued in 1997 , and so far is the only IP regulation with a specific focus on traditional arts and crafts. It has been widely acknowledged that intellectual property is not only an e-ISSN: 2407-392X. p-ISSN: 2541-0857 
economic phenomenon but also a cultural one (Raustiala and Sprigman 2014: 4), which has particular implications in the traditional Chinese crafts industry. The authors Marron and Steel (2000, p. 166) were once informed by a reputable craftsperson that it is a cultural tradition within the crafts community that one should not claim individual ownership of their craft work, because it is considered to be a 'public good', which others were therefore allowed to imitate (ibid). This is largely due to the traditional Chinese mind-set of collectivism, but also through the nature of crafts industry being institutional or communal. Many believe that through sharing, the original creation can be further enhanced through "co-innovation and reinnovation based on the assimilation of imported technologies" (Raustiala and Sprigman 2014:3).

\section{Brand Promotion as A Solution}

One of the successful tactics that many luxury brands adopt in promoting their products is to showcase the craftsmanship involved in the construction of the final piece of work. A successful luxury brand would usually first make their name within their own domestic market before expanding to overseas markets. According to Bain \& Company (2018), Chinese consumers constitute more than $30 \%$ of global luxury consumption, and the http://ojs.unud.ac.id/index.php/eot millennial generation (typically aged 2034) have become major contributors to this. In the face of a younger generation of consumers who clearly have stronger spending power and brand value perception, Chinese traditional crafts have not been very effective in drawing their attention, which is a frequent complaint by craft producers surveyed by the authors of this paper. Whilst it is not too late to target the younger Chinese, the principal question is how? Research studies have identified one type of young Chinese luxury consumers as 'spirituals' (Ngai 2012) who have the capacity genuinely to understand and appreciate the aesthetic and social value of objects, and who also pursue associated experiences beyond the material.

The documentary programme "Masters in the Forbidden City", which was broadcast on China Central Television in early 2016, became surprisingly popular among the young Chinese audience who mostly accessed the episodes through online streaming and tagged the programme as the new 'online influencer' (Global Times 2016). The documentary depicted the life stories of craftspeople preserving and restoring antique works for the Forbidden City Palace Museum, and the success of the documentary sent a clear message: the modern methods used to reinterpret traditional culture now can not only form a bridge between history and 
make connection with current realities (Song, 2017, 160), but can also build a cultural and emotional connection to young people that rejuvenates their love of 'good culture' (ibid).

\section{Brand Inheriting is A Mission}

If it is true that China has been in danger of losing her grassroots essentials of traditional crafts because of political changes and economic development, these paradoxically may be seen as a basis for the revival and perpetuation of China's historical and cultural heritage. In order to sustain the brands of the traditional Chinese crafts, the skills and essence of craftsmanship must be passed onto the next generation, so education and training must be viewed as the first and foremost component. In 2012 the Ministry of Education re-introduced 'gong yi mei shu' (art and craft) into the university undergraduate course catalogue after decades of absence.

Chinese scholars Tang and Tao (2014) nonetheless admit that universities face challenges to implement the new course catalogue, but can possibly attempt to do so in three areas: to prioritise and incorporate local crafts which manifest regional characteristics; to invite the experienced craft masters into the lecture room to demonstrate the empirical skills that complement the theories they are http://ojs.unud.ac.id/index.php/eot learning; and to incorporate innovative ideas related to culture and modern life into the building of the curriculum. An interview with an art scholar Mr. Li from Shanghai adds further reflection on the theme of this paper: he believes that the national policy to promote 'craftsmanship' indicates the government's intention to elevate the social status of craftspeople and their craft works, with the universities acting as one of first gateways to set this in motion.

On the other hand, a few Chinese Haute Couture brands Guo Pei and Lan Yu have managed to make their way to Paris and exhibit their collections since 2016. And what has contributed to their success apart from the Chinese themes embedded within their designs - is the unique craftsmanship: the traditional embroidery techniques the designers have applied to enable them to deliver unique, exquisite and luxury pieces on the Paris fashion stages.

\section{CONCLUSION: \\ A STRATEGIC DEVELOPMENT TRAJECTORY}

As academics with their particular research focus on the luxury industry and cultural tourism and museums, we would argue that there is a great deal to learn from history. But this is not an anti-development position as it is clear that human society 
should and will develop for myriad good and beneficial reasons, but sometimes we have to surrender to the truth that history repeats itself and we have to take stock and reflect on what happened in the past, and what we can do to improve upon it. Chinese handicrafts are simultaneously commodities and heritage-cum-pride goods that have their roots deeply embedded in Chinese history going back to at least the Zhou Dynasty if not earlier. Even if we need not take at face value the declared love of the early leaders of the Peoples' Republic of China for time-honoured brands, it would seem to indicate that they were voicing perhaps a commonly held view. The proliferation of museums across China at both grand and city level to smaller village-based ones devoted to crafts seems to indicate a string and widespread interest in the country's craft heritage.

However, we need to be cautious as China has been undergoing for some decades an enormous transformation in terms of industrialisation and urbanisation, and it seems reasonable to assume that this may be accompanied in paradigm shifts in terms of consumer behaviour. For example, a study from Anshan City in Liaoning Province that Chinese consumers are undergoing a Romantic reappraisal of rurality in contradistinction to the symbolic infrastructure of mass urbanisation and industrialisation that may have some http://ojs.unud.ac.id/index.php/eot similarities to the sentiments of the British and West European Romantic Period in the late 18th and early 19th centuries that followed a massive wave of industrialisation there (Griffiths, Chapman and Christiansen, 2010). There are good reasons for linking this reappraisal to tourism as Hitchcock and Barsham (2013) have explored what they call 'prophets of nature' and the ongoing relevance of Romantic ideals in considerations of the relationship between tourism and the environment. This is perhaps one of the areas that we should be investigating when consider the sustainability and authenticity - however conceived- of Chinese traditional crafts.

\section{REFERENCES}

Bain \& Company (2018), After a three-year deceleration, domestic China luxury market started to rebound in 2016 and achieved 20\% growth in 2017. Available at: https://www.bain.com/about/mediacenter/press-releases/2018/chinaluxury-report-2018 (Accessed on: 25 June 2018).

Barclay, A. (2017), Follow Me: Luxury Brands Turn to Social Media to Connect with Customers. South China Morning Post $\left(10^{\text {th }}\right.$ October, 2017) https://www.scmp.com/business/com panies/article/2114756/follow-meluxury-brands-turn-social-mediaconnect-customers. 
Bergadaà, M. (2008) 'Craftsmen of art, and their craft: the experience of authenticity and its materialization in the places where craftspeople and enlightened clients meet', Recherche et Applications en Marketing (English Edition), 23(3), pp. 5-24. doi:10.1177/205157070802300302.

Bruner, E. (2005), Culture on tour: ethnographies of travel. Chicago: University of Chicago Press.

Chang, J., Wall, G. \& Chang, C-L. (2008), 'Perception of the Authenticity of Atayal Woven Handicrafts in Wulai, Taiwan', Journal of Hospitality \& Leisure Marketing, 16(4), pp. 385409.

doi: 10.1080/10507050801951700.

Coeckelbergh, M. (2014) 'Moral craftsmanship', in Moran, S., Cropley, D. \& Kaufman, J.C. (eds.) The ethics of creativity. London: Palgrave Macmillan, pp. 46-61.

China Daily (2011) 'Time-Honored Brands Praised by Mao Zedong, Zhou Enlai and Deng Xiaoping' (15 ${ }^{\text {th }}$ August, 2011)

http://www.chinadaily.com.cn/china/ 19thcpcnationalcongress/201108/15/content_29579095.htm.

Cohen, E. (1988)' Authenticity and commoditization in tourism', Annals of Tourism Research, 15 (3), pp. 371386.

Cohen, E. and Cohen, S.A. (2012), 'Authentication: hot and cool', Annals of Tourism Research, 39(3), pp. 1295-1314.

Corrigan, G. (2002) Guizhou Province: Costume and Culture in Remote China. Guiyang: Ghuizhou Overseas Travel Corporation.

Eno, R. (2010) 'Mohist thought', Indiana University, Early Chinese Thought [B/E/P374] - Fall 2010. Available at: http://www.iub.edu/ p374/Mohism.p df (Accessed on: 31 July 2018).
Ernst \& Young. (2012) Competitive study on handicrafts sector in China. New Delhi: Export Promotion Council for Handicrafts. Available at: http://www.epch.in/ChinaStudy/Rep ort.pdf (Accessed on: 26 July 2018).

Europol \& EUIPO. (2017) 2017 Situation Report on Counterfeiting and Piracy in the European Union. Alicante: EUIPO. Available at: https://euipo.europa.eu/tunnelweb/secure/webdav/guest/document _library/observatory/documents/repo rts/Situation\%20Report\%20EUIPOEuropol_en.pdf (Accessed on: 30 June 2018).

Fritz, K., Schoenmueller, V. \& Bruhn, M. (2017), 'Authenticity in branding exploring antecedents and consequences of brand authenticity', European Journal of Marketing, 51(2), pp. 324-348. doi: 10.1108/EJM-10-2014-0633.

葛亮亮; 王珂. (2018) ‘你好！我是中华老 字号......', 人民日报.6月5日.

Ge, L-L. \& Wang, K. (2018) 'Ni hao! Wo shi zhong hua lao zi hao.....', People's Daily. $5^{\text {th }}$ June. Available at: http://paper.people.com.cn/rmrb/htm 1/201806/05/nw.D110000renmrb_2018060 5_1-06.htm (Accessed on: 18 July 2018).

Gilmore, J.H. \& Pine, J. (2007), Authenticity: What Consumers Really Want, Boston: Harvard Business School Press.

Global Times (2016), Antique repair documentary becomes unexpected hit among China's youth. Available at: http://www.globaltimes.cn/content/9 69784.shtml (Accessed on: 25 June 2018). 
Graburn, N. (1984) 'The evolution of tourist arts', Annals of Tourism Research, 11(3), pp. 393-419. doi: 10.1016/0160-7383(84)90029-X.

Graburn, N. (2000) Foreword in Hitchcock, M \& Teague, K. (ed.) (2000) Souvenirs: The Material Culture of Tourism. Aldershot: Ashgate, pp. xiixvii.

Greenhalgh, P. (1997), 'The history of craft', in P. Dormer (ed.), The Culture of Craft: Status and Future. Manchester: Manchester University Press, pp. 20-52.

Greenhalgh, P. (ed.) (2002), The Persistence of Craft: The Applied Arts Today. London: A\&C Black.

Greenhalgh, P. (2010) 'The History of craft', in Lees-Maffei, G \& Houze, R. (eds.) The Design History Reader. Oxford \& New York: Berg Publishers, pp. 329-335.

Hede, A-M., Garma, R., Josiassen, A. \& Thyne, M. (2014), 'Perceived authenticity of the visitor experience in museums: Conceptualization and initial empirical findings', European Journal of Marketing, 48 (7/8), pp.1395-1412. doi: 10.1108/EJM-122011-0771.

Griffiths, M.B., Chapman, M. and Christiansen, F. (2010) Chinese consumers: the Romantic reappraisal, Ethnography, 11:3, pp. 331-357.

Heine, K., Phan, M. \& Atwal, G. (2016), 'Authenticity and prestige: what luxury brands could learn from the wine industry?', Luxury Research Journal, 1(2), pp. 177-190. doi: 10.1504/LRJ.2016.078127.
Hitchcock, M \& D. Barsham (2013), 'Prophets of nature: romantic ideals of nature and their continuing relevance to tourism today' In Holden, A. \& Fennell , D (eds) The Routledge Handbook of Tourism and the Environment. London; Routledge pp. 54-64.

Hitchcock, M \& Teague, K. (ed.) (2000) Souvenirs: The Material Culture of Tourism. Aldershot: Ashgate.

Hitzler, P. A. \& Müller-Stewens, G. (2017), 'The strategic role of authenticity in the luxury business', in Gardetti, M.A. (ed.) Sustainable Management of Luxury. Singapore: Springer Singapore, pp. 29-60.

$\mathrm{Hu}$, Yongqi. (2017), 'Plan to revitalize traditional crafts', China Daily USA. 5 April. Available at: http://usa.chinadaily.com.cn/epaper/ 2017-04/05/content_28802519.htm (Accessed on: 22 June 2018).

Kapferer, J.N. \& Bastien, V. (2012) The Luxury Strategy: Break the Rules of Marketing to Build Luxury Brands. London: Kogan Page.

Lau, R.W.K. (2010), 'Revisiting authenticity: a social realist approach', Annals of Tourism Research, 37 (2), pp. 478-498.

Kim, H. \& Bonn, M. A. (2016) 'Authenticity: Do tourist perceptions of winery experiences affect behavioral intentions?', International Journal of Contemporary Hospitality Management, 28 (4), pp. 839-859. doi:10.1080/13683500.2010.493607.

李飞;马燕. (2017) '中国能打造出世界级 奢侈品品牌吗?'，清华管理评论， 2017(1/2), pp. 40-47. 
Li, F. \& Ma, Y. (2017) 'Zhong guo neng da zao chu shi jie ji she chi pin pin pai ma?', Tsinghua Business Review, 2017(1/2), pp. 40-47 http://crrc.sem.tsinghua.edu.cn/u/cm s/crrc/201703/130756557zc5.pdf.

Liu, M.j., Yannopolou, N., Bian, X., and Elliott, R. (2015), 'Authenticity perceptions in the Chinese marketplace', Journal of Business Research, 68:1, 27-33.

MacCannell, D. (1973), 'Staged authenticity: arrangements of social space in tourist settings', American Journal of Sociology, 79 (3), pp. 598603.

Marron, D. B. \& Steel, D. G. (2000), 'Which countries protect intellectual property? The case of software piracy', Economic Inquiry, 38 (2), pp. 159-174.

Ngai, J \& Cho, E. (2012), 'The young luxury consumers in China', Young Consumers, 13(3), pp. 255-266. doi: 10.1108/17473611211261656.

Parnwell, M. (1993), 'Tourism and rural handicrafts in Thailand', in Hitchcock, M., King, V. \& Parnwell, M (eds.) Tourism in South-East Asia. London \& New York: Routledge, pp. 234-257.

Ramkissoon, H \& Uysal, M.S. (2011), 'The effects of perceived authenticity, information search behaviour, motivation and destination imagery on cultural behavioural intentions of tourists', Current Issues in Tourism, 14(6), pp. 537-562. doi:10.1080/13683500.2010.493607.
Raustiala, K. and Sprigman, C. J. (2014), 'Let them eat fake cake: e rational weakness of China's anticounterfeiting policy', New York University Law and Economics Working Papers. Paper 376. Available at: http://lsr.nellco.org/nyu_lewp/376 (Accessed on: 25 June 2018).

Risatti, H. (2007), A Theory of Craft: Function and Aesthetic Expression, Chapel Hill: University of North Carolina Press.

Selwyn, T. (ed.) (1999), The Tourist Image: Myth and Myth Making in Tourism, Chichester: Wiley.

Sennett, R. (2008), The Craftsman, New Haven \& London: Yale University Press.

Shiner, L. (2012), 'Blurred boundaries"? Rethinking the concept of craft and its relation to art and design', Philosophy Compass, 7(4), pp. 230-244. doi: 10.1111/j.1747-9991.2012.00479.x.

Song, Y. (2017), 'Analysis of Successful reason of "Masters in Forbidden City", in 2017 4th International Conference on Literature, Linguistics and Arts (ICLLA 2017), 7-9 July 2017, Guilin, China. London: Francis Academic Press. pp. 159-164. Available at: https://webofproceedings.org/procee dings_series/ESSP/ICLLA\%202017/ ICLLA_082537.pdf (Accessed on: 26 July 2018).

Steiner, C.J. \& Reisinger, Y. (2006) Understanding Existential Authenticity. Annals of Tourism Research, 33 (2), pp.299-318. 
UNESCO \& ITC. (1997), 'Adoption of recommendations and plan of action (item 6 of the agenda)', in International symposium on "crafts and the international market: trade and customs codification" final report, 6-8 October 1997, Manila. Switzerland: International Trade Centre UNCTAD/WTO. pp. 6-10. Available at: http://unesdoc.unesco.org/images/00 11/001114/111488eo.pdf (Accessed on: 17 June 2018).

State Council of the PRC. (1997) Regulations on protection of traditional arts and crafts. Available at:

http://www.wipo.int/wipolex/en/text. jsp?file_id=198447 (Accessed on: 22 June 2018).

唐胜天, 陶珂. (2014) ‘关于教育部重设工 艺美术专业的思考，艺术探索， 28(6), pp. 56-58. doi: 10.13574/j.cnki.artsexp.2014.06.013.

Tang, Sh-T. \& Tao, K. (2014), 'Guan yu jiao yu bu chong she gong yi mei shu zhuan ye de si kao', Yi Shu Tan Suo, 28(6), pp. 56-58. doi: 10.13574/j.cnki.artsexp.2014.06.013.

Thornton, P. H. (2002), 'The rise of the corporation in a craft industry: conflict and conformity in institutional logics', Academy of Management Journal, 45(1), pp. 81101. doi: $10.5465 / 3069286$.

田自秉. (2010) 中国工艺美术史. 修订本. 上海: 东方出版中心.

Tian, ZB. (2010) Zhong guo gong yi mei shu shi. Xiu Ding Ben. Shanghai: Dong Fang Chu Ban Zhong Xin.
Wherry, F. (2006), 'The Social Sources of Authenticity in Global Handicraft Markets Evidence from Northern Thailand', Journal of Consumer Culture, 6(1), pp. 5-32. doi: 10.1177/1469540506060867.

UNESCO \& ITC. (1997) 'Adoption of recommendations and plan of action (item 6 of the agenda)', in International symposium on "crafts and the international market: trade and customs codification" final report, 6-8 October 1997, Manila. Switzerland: International Trade Centre UNCTAD/WTO. pp. 6-10. Available at: http://unesdoc.unesco.org/images/00 11/001114/111488eo.pdf (Accessed on: 17 June 2018).

UNESCO. (2016) The globalisation of cultural trade: a shift in consumption: international flows of cultural goods and services 20042013. Montreal, Quebec: UNESCO Institute for Statistics. Available at: http://dx.doi.org/10.15220/978-92-

9189-185-6-en (Accessed on: 30 June 2018).

Van Bergen, R. (2017), In Europe, skilled craftsmanship is luxury. Why not in the rest of the world, too? Available at:

https://www.weforum.org/agenda/20 17/03/artesans-skilledcraftsmanship-equality-nest (Accessed on: 18 June 2018).

Wang, N. (1999), 'Rethinking Authenticity in Tourism Experience', Annals of Tourism Research, 26(2), pp. 349370.

许纪霖. (2016) 中国人为何缺少“工匠精 神”? 
$\mathrm{Xu}$, Jilin. (2016) Zhong guo ren wei he que shao "gong jiang jing shen"? Available at: https://pit.ifeng.com/a/20160623/492 23659_0.shtml (Accessed on: 17 June 2018).

朱孝岳. (2009) “关于“工艺美术”一词的 几点诠释, 装饰, 2009(12), pp. 2527. doi: 10.16272/j.cnki.cn111392/j.2009.12.010

Zhu, XY. (2009) 'Guan yu "gong yi mei shu" yi ci de ji dian quan shi (A Few Comments On the Concept of Arts \& Crafts)', Zhuang Shi, 2009(12), pp. 25-27.

朱孝岳, 徐勤. (2010) 设计概论. 第二版. 北京: 高等教育出版社.

Zhu, XY \& Xu, Q. (2010) She ji gai lun. $2^{\text {nd }}$ edn. Beijing: Gao deng jiao yu chu ban she. 